\title{
THE CJEU: AN OVERZEALOUS ARCHITECT OF THE RELATIONSHIP BETWEEN THE EUROPEAN UNION LEGAL ORDER AND THE INTERNATIONAL ONE?
}

DOI: $10.47743 /$ rdc-2016-1-0003

\author{
Dr. Szilárd GÁSPÁR-SZILÁGYI \\ Postdoctoral Researcher, University of Amsterdam, \\ Centre for European Law and Governance
}

\section{Abstract}

The current article provides a critical overview of the CJEU's role as the main "architect" of the relationship between the EU legal order and the international legal order. The activities of the CJEU are assessed in light of four parameters: the protection of fundamental rights, the protection of the internal division of competences within the $E U$, issues of primacy and review of legality when international agreements are present, and the relationship between the CJEU and other international tribunals. It is argued that the CJEU in the last decade is increasingly acting in a fashion similar to federal constitutional courts that seek to protect the 'federal' level legal order from the intrusions of the international legal order and those of the sub-federal level. In its quest to protect the autonomy of the EU legal order and its own exclusive jurisdiction in a multilevel, pluralistic legal system, the CJEU might have caused more harm than good, affecting legal certainty, and the dialogue between it and the international legal order or international tribunals.

Keywords: CJEU; autonomy of EU legal order; fundamental rights; division of competences; review of legality; international courts

\section{Introduction}

Different legal orders provide for different supreme judicial authorities. Some legal orders, such as the United States ${ }^{1}$ and The Netherlands ${ }^{2}$ only have a Supreme Court, while other legal orders, such as Romania, will provide for both a Supreme ${ }^{3}$ and a

\footnotetext{
${ }^{1}$ Article III, Section 1 , US Constitution.

${ }^{2}$ Article 118 of the Constitution of the Kingdom of The Netherlands (English), available at https://www.government.nl/documents/regulations/2012/10/18/the-constitution-of-the-kingdom-of-the-nether lands-2008, accessed 27 January 2016.

3 Article 126 of the Constitution of Romania (English), available at http://www.cdep.ro/pls/dic/site. page?id=371, accessed 27 January 2016.
}

CONSTITUTIONAL LAW REVIEW 
Constitutional Court ${ }^{4}$. When it comes to federal or federal like systems, the highest judicial authority can also be constituted of one or several courts ${ }^{5}$, most often embedded in a system of federal courts ${ }^{6}$.

Highest constitutional courts in a federal or a federal like system have a triple hatted role. First, they need to strengthen and uphold the existence and functioning of the federal constitutional order in relation to the sub-federal level constituent entities ${ }^{7}$ and also in relation to the other branches of the federal government ${ }^{8}$. Second, these highest courts need to elaborate on the relationship between their own legal orders and the international one. Third, such courts are/can be tasked with the interpretation, application and validation of the federal level legal instruments and with the interpretation of the highest constitutional norms in the land.

The Court of Justice of the European Union (CJEU, the Court) is neither a traditional constitutional court, nor a supreme court. Its roots are not to be found in a national constitution, but international treaties signed between sovereign states that gave up part of their sovereignty to the newly created regional economic entity. Thus, from a public international law perspective, the CJEU is an international/regional court that is tasked with the supervision of several international agreements setting up a regional economic organization, the European Union. However, such a definition of the Court and its functions is short-sighted. From an EU law perspective the CJEU in many ways combines the functions of a federal-type constitutional and/or supreme court, while possessing powers which are inherent to its set-up.

First, the Court has developed principles and mechanisms (for e.g. primacy, direct effect $)^{9}$ which define the relationship between the EU legal order, on the one side, and the Member State legal orders on the other. Furthermore, it has also developed legal doctrines (for e.g. institutional balance, deference to the EU executive or legislative) ${ }^{10}$ to describe the relationship between the different EU level actors. Second, the CJEU created an intricate jurisprudence on the relationship between the EU legal order and

\footnotetext{
4 Title $\mathrm{V}$ of the Constitution of Romania.

${ }^{5}$ Germany for example has a multitude of federal supreme courts in various legal areas: The Federal Court of Justice/Bundesgerichtshof (criminal and private law), The Federal Administrative Court (Bundesverwaltungsgericht), The Federal Labour Court (Bundesarbeitsgericht), The Federal Social Court (Bundessozialgericht), The Federal Finance Court (Bundesfinanzhof) and The Federal Constitutional Court (Bundesverfassungsgericht). See Basic Law of the Federal Republic of Germany (English), available at https://www.bundestag.de/blob/284870/ce0d03414872b427e57fccb703634dcd/basic_law-data.pdf, accessed 27 January 2016.

${ }^{6}$ See Article III, Section 1, US Constitution. The US federal judiciary consists of 94 federal district courts, 12 federal courts of appeal, a Supreme Court, as well as bankruptcy courts and courts of special jurisdiction. See http://www.uscourts.gov/about-federal-courts, accessed 27 January 2016.

7 The issue of federalism or the vertical separation of powers.

8 The issue of the horizontal separation of powers.

${ }^{9}$ Case 6/64, Flamino Costa v. ENEL [1964] ECR 585; Case 26/62, Van Gend en Loos v. Nederlandse Administratie [1963] ECR 1.

${ }^{10}$ Case C-149/96, Portugal v. Council [1999] ECR I-08395, para. 40.
} 
the international one ${ }^{11}$. Third, even if no federal-type EU level court system exists ${ }^{12}$, the CJEU as one of the institutions of the EU is charged with the interpretation, application and validation of secondary EU legal instruments, and with the interpretation of primary EU law ${ }^{13}$. Fourth, through the preliminary reference mechanism the CJEU engages in a judicial dialogue with the courts of the Member States.

This article will focus on the second function of the CJEU, as the main "architect" of the relationship between the EU legal order and the international legal order. In order to have a complete picture of this relationship, four parameters are used: EU fundamental rights (Part II), the division of competences between the EU and the Member States (Part III), the primacy of international law and the review of legality of secondary EU law (Part IV), and the relationship between the CJEU and other international courts or tribunals (Part V). Part VI is reserved for concluding observations. This article also draws on previous and ongoing research of this author, with adequate references made.

\section{EU fundamental rights. A step too far?}

Every major democratic constitutional legal order, based on the rule of law, has a basic set of fundamental rights which belong to the highest norms of the land that all actors of the polity must conform to. In the United States the first ten Amendments to the US Constitution ('The Bill of Rights') define as constitutional norms the freedom of religion, the freedom of speech and press, the right to bear arms, due process etc. ${ }^{14}$. The Romanian Constitution in Title II, Chapter II also includes an extensive set of fundamental rights and freedoms. However, the Member States of the EU, besides their national fundamental rights regimes, also participate in the fundamental rights protection guaranteed by the European Convention on Human Rights ("ECHR"), alongside other European Sates, and as members of the EU, they also participate in the fundamental rights regime of the EU. In other words, they are the participants in a multilevel, pluricentric regime of fundamental rights protection.

When it comes to the protection of fundamental rights, the EU is not that different from most constitutional legal orders and by now possesses an advanced system of fundamental rights protection. However, the road to the current stage in EU fundamental rights protection was not an easy one. As mentioned, the birth of the former Community and the current EU is not to be found in a national federal constitution, but in a set of international agreements. This would mean that the EU legal order is just a branch of the international legal order. However, the first step the CJEU

\footnotetext{
11 See Section IV.

${ }^{12}$ A proposal to establish a system of decentralized, regional courts on a European level existed, but was not taken up. See P. Craig, G. de Búrca, EU law. Text, Cases and Materials (OUP, 2008), p. 63.

13 See Article 267 TFEU and Article 19 TEU.

${ }^{14}$ See US Constitution, Amendments 1-10.
}

CONSTITUTIONAL LAW REVIEW 
took when constructing the EU legal order was to acknowledge that the EU "constitutes a new legal order of international law for the benefit of which the states have limited their sovereign rights"15 and which is separate from the international legal order. In other words, the CJEU took the former EEC Treaty outside the ambit of international law and created a new legal order, which needed a set of constitutional norms of its own. Even so, up until recently the Founding Treaties (TEU, TFEU, former EC Treaty) did not contain a binding, written "Bill of Rights" similar to the ones found in the afore-mentioned constitutions.

The second step in developing the EU constitutional legal order was acknowledging that the Founding Treaties did not only concern economic rights and economic integration, but also fundamental rights and freedoms. This has been a long process that involved both CJEU jurisprudence, amendments to the Founding Treaties and the opposition of certain Member State courts $^{16}$. In Nold (1974) the CJEU held that "fundamental rights form an integral part of the general principles of law, the observance of which it ensures"17. When safeguarding these rights the Court has to draw inspiration from the constitutional traditions common to the Member States, and international human rights treaties to which Member States are signatories shall supply interpretation guidelines ${ }^{18}$. In Hauer (1979) the CJEU has specifically referred to the first Protocol of the ECHR when interpreting the right to property ${ }^{19}$, while in Henn \& Darby (1979) the CJEU used the margin of appreciation of states doctrine, a concept developed by the European Court of Human Rights (ECtHR $)^{20}$.

In 1986 the Single European Act, unlike its predecessor the 1957 EEC Treaty of Rome, referred expressly in its preamble to the fundamental rights "recognized in the constitutions and laws of the Member States", in the ECHR and the European Social Charter. 1992 saw the inclusion of the respect of fundamental rights in the actual EU Treaty text (Article F), while the Treaty of Nice introduced the then not yet binding EU Charter of Fundamental Rights ('EU Charter'). By the time Schmidberger ${ }^{21}$ was handed down in 2003, the CJEU's fundamental rights jurisprudence showed maturity, as the

\footnotetext{
${ }^{15}$ Case 26/62, Van Gend en Loos [1963] ECR 1, p. 12.

16 On the highly discussed issue of the relationship between MS constitutional courts and the CJEU, see D. Piqani, The Role of National Constitutional Courts in Issues of Compliance, in M. Cremona (ed.), Compliance and the Enforcement of EU Law (OUP, 2012); D. Halberstam, Ch. Möllers, The German Constitutional Court says "Ja zu Deutschland!", (2009) 10(8) German Law Journal 1241; J. Komárek, Playing with Matches: The Czech Constitutional Court Declares a Judgment of the Court of Justice of the EU Ultra Vires; Judgment of 31 January 2012, Pl. ÚS 5/12, Slovak Pensions XVII' (2012) 8 European Constitutional Law Review 323; L.I. Gordillo, Interlocking Constitutions. Towards and Interordinal Theory of National, European and UN Law (Hart Publishing, 2012), pp. 18-25.

${ }^{17}$ Case 4-73, Nold v. Commission [1974] ECR 491, para. 13.

18 Ibidem.

${ }^{19}$ Case 44/79, Liselotte Hauer v. Land Rheinland-Pfalz [1979] ECR 3727, para. 17.

${ }^{20}$ Case 34/79, Regina v. Maurice Henn and John F.E. Darby [1979] ECR 3795, para. 15. See also Handyside v. United Kingdom (5493/72) [1976] ECHR 5 (7 December 1976).

${ }^{21}$ Case C-112/00, Schmidberger v. Austria [2003] ECR I-5659.
}

STUDIES AND ARTICLES 
CJEU was willing to justify the restriction of the EU right to free movement of goods in order to protect the freedom of expression and the right to protest.

The third step consists of developments that have occurred in the last decade. This period brought significant changes to the EU fundamental rights regime, through the Court's Kadi jurisprudence, the entry into force of the EU Charter of Fundamental Rights and the recent Opinion 2/13 on the EU's Accession Agreement to the ECHR. Let us look shortly at these developments.

Kadi $1^{22}$ in many ways can be considered one of the major building blocks of the EU's constitutional legal order. Until Kadi I, the Court had created an EU legal order that provided for directly effective legal norms in the Member States' legal orders ${ }^{23}$, the primacy of EU law over any type of national law ${ }^{24}$ and the non-contractual liability of Member States for breaches of EU law ${ }^{25}$. However, all these developments considered the relationship between the EU legal order and the MS legal orders. Kadi I on the other hand became a major building block in the relationship between EU law and international law. The Court famously held in para. 285 of the judgment that "an international agreement [UN Charter] cannot have the effect of prejudicing the constitutional principles of the [EU Treaties], which include the principle that all [EU] acts must respect fundamental rights". All of a sudden, we find a bold and a much more assertive CJEU that decided to elevate EU fundamental rights protection to such constitutional heights that not even the most supreme sources of international law (UN law) could touch it.

While this dualist stance towards international law has been at the centre of heated academic debates ${ }^{26}$, some viewing it as a departure from the Court's more open policy towards international law, according to other authors "the choice of a somewhat dualist approach in this particular context has to be understood as a reaction to a specific situation that may occur in a multilevel system" ${ }^{27}$. According to Lavranos, the EU legal order must be regarded as a separate legal order that does not belong to either the national or the international legal orders. The consequence of this is that EU law is not subordinate to international law, but rather exists side by side and on the same

\footnotetext{
22 Joined Cases C-402/05 P and C-415/05 P, Kadi and Al Barakaat International Foundation v. Council and Commission (Kadi I) [2008] ECR-06351. This was followed by Joined Cases C-584/10 P, C-593/10 P and C-595/10 P, European Commission and others v. Kadi (Kadi II) [2013] ECLI:EU:C:2013:518.

${ }^{23}$ Van Gend en Loos, quoted supra, n. 9.

${ }^{24}$ Case 106/77, Amministrazione delle Finanze dello Stato v. Simmenthal SpA [1978] ECR 629. See E. Stein, Lawyers, Judges, and the Making of a Transnational Constitution (1981) 75 American Journal of International Law 1, p. 13.

${ }^{25}$ Joined Cases C-6/90 and C-9/90, Francovich v. Italian Republic [1991] ECR I-05357.

${ }^{26}$ See G. De Burca, The EU, the European Court of Justice and the International Legal Order after Kadi (2009) 51(1) Harvard International Law Journal; A. Gattini, Joined Cases C-402/05 P \& 415/05 P, Yassin Abdullah Kadi, Al Barakaat International Foundation v. Council and Commission, judgment of the Grand Chamber of 3 September 2008, nyr.' (2009) 46(1) Common Market Law Review 213.

27 J. Kokott and Ch. Sobotta, The Kadi Case - Constitutional Core Values and International Law - finding the Balance (2012) 23(4) European Journal of International Law 1015, p. 1018.
} 
level with the international legal order. Therefore, international law cannot "superimpose" itself over EU law, but must accept the internal hierarchy of norms within the EU legal order ${ }^{28}$.

Kadi I evidences a much more mature Court which finds itself in a similar situation to the German Constitutional Court in its Solange affair ${ }^{29}$. This new Court is not against the enforcement of international obligations per se, provided such commitments do not infringe the constitutional standards of the EU to which fundamental rights also belong to. Unlike the Court of First Instance (now the General Court) ${ }^{30}$, the CJEU decided to choose a lot more Eurocentric stance, and was willing to protect the core values of the EU legal order even if this meant a possible upset of the relations between the EU, its Member States and the $U^{31}$.

The recent developments do not stop here. Following the entry into force of the Lisbon Treaty, the EU Charter became fully binding and has the same legal value as the Founding Treaties (Article 6 para. 1 TEU). The Charter is addressed to the EU institutions and having regard to the principle of subsidiarity, also to the Member States, but "only when they are implementing EU Law". ${ }^{32}$ Furthermore, under Article 6 para. 3 TEU fundamental rights as guaranteed by the ECHR and as they result from the common constitutional traditions of the Member State constitute general principles of EU law. Even more, the EU is now under a duty to accede to the ECHR under Article 6 para. 2 TEU. Therefore, for the first time in its history the EU has its own fully binding, written "Bill of Rights", the ultimate guarantor of which is the CJEU. Still, the TEU provisions consolidate the role of the ECHR and the common constitutional traditions of Member States. Article 52 para. 3 of the Charter even provides that in so far as the Charter contains rights which correspond to rights under the ECHR "the meaning and scope of those rights shall be the same as those laid down by the said Convention".

So at this point one would conclude that the EU finally has a full system of fundamental rights protection, which is clearly delimited from the international legal order, but which also keeps its close ties to the ECHR and the meanings given to

\footnotetext{
${ }^{28}$ N. Lavranos, The Interface between European and National Procedural Law: UN Sanctions and Judicial Review, in D. Obradovic, N. Lavranos (eds), Interface Between EU Law and National Law (Europa Law Publishing, 2007), pp. 356-357.

${ }_{29}$ Case BvL 52/71, Solange I [1974] BVerfGE 37, 271; Case 2 BvR 197/83, Solange II [1986] BVerfGE 73, 339; Case 2 BvR 2134, 2159/92, Maastricht Judgment [1993] BVerfGE 89, 155; Case 2 BvE/08, Lisbon Judgment [2009] BVerfGE.

${ }^{30}$ T-315/01, Kadi v. Council and Commission [2005] ECR II-3649. The General Court originally held that it could not review EU measures implementing UN Security Council Resolutions since that would undermine the supremacy of UN law. It chose instead, unconvincingly, to conduct a review in light of "jus cogens". For further reading, see M. Avbelj, F. Fontanelli, G. Martinico (eds), Kadi on Trial. A Multifaceted Analysis of the Kadi Trial (Routledge, 2014).

${ }^{31}$ In the end this landmark judgment exerted pressure on the UN Sanctions Regime and lead to the creation of the Office of the Ombudsperson. See Office of the Ombudsperson of the UN Security Council's 1267 Committee, available at https://www.un.org/sc/suborg/en/ombudsperson, last visited 29 January 2016.

${ }^{32}$ Article 51 para. 1 of the EU Charter of Fundamental Rights.
}

STUDIES AND ARTICLES 
fundamental rights by the ECtHR. However, Opinion $2 / 13^{33}$ seems to contradict this and represents a new step in the CJEU's consolidation of the EU's fundamental rights regime. In, by the now infamous Opinion, the CJEU essentially decided that the Agreement on the Accession of the EU to the ECHR was not compatible with the EU legal order, mainly because the autonomy of the EU legal order and the autonomy of the Court's interpretative powers were not sufficiently guaranteed by the envisaged agreement. Among others, the CJEU considered that the Accession Agreement would subject Luxembourg to the decisions and judgments of Strasbourg, thus binding the EU and its institutions to a particular interpretation of EU law ${ }^{34}$.

The academic commentary that ensued is mostly negative ${ }^{35}$. Halberstam is one of the few commentators that have tried to provide a partial defence of this Opinion by looking at its constitutional significance. According to him, the CJEU adopted a pluralistic approach to the relationship between EU and ECHR law. Under constitutional pluralism the EU's constitutional architecture need not displace all other claims of constitutional authority from within or outside of the $\mathrm{EU}^{36}$ and the CJEU will continue applying outside norms, as long as they do not conflict with certain core constitutional principles of the EU legal order ${ }^{37}$. In this new multilevel, pluralistic system of fundamental rights protection all three major actors, the CJEU, the Member State high or constitutional courts, and the ECtHR will claim final authority, while acknowledging the application of outside norms, as long as the fundamental rights protection is equivalent. However, it seems that in Opinion 2/13 the CJEU adopted a more radical version of pluralism than the softer versions of constitutional pluralism ${ }^{38}$. Under this radical version the Court is the only and final arbiter over EU law.

One might ask the question whether such a radical interpretation of pluralism was called for. We have seen that both the German Constitutional Court and the ECtHR ended up opting for a soft version of pluralism. Both courts in the end, under their

\footnotetext{
33 Opinion 2/13 (Accession to the ECHR) [2014] ECLI:EU:C:2014:2454.

34 Ibidem, para. 181.

35 (2015) 16(1) German Law Journal, Special Section - Opinion 2/13: The EU and the European Convention on Human Rights. See: D. Halberstam, "It's the Autonomy, Stupid!" A Modest Defense of Opinion 2/13 on EU Accession to the ECHR, and the Way Forward; Ch. Krenn, Autonomy and Effectiveness as Common Concerns: A Path to ECHR Accession After Opinion 2/13; S. Øby Johansen, The Reinterpretation of TFEU Article 344 in Opinion 2/13 and Its Potential Consequences; A. Lazowski, R.A. Wessel, When Caveats Turn into Locks: Opinion 2/13 on Accession of the European Union to the ECHR; S. Peers, The EU'S Accession to the ECHR: The Dream Becomes a Nightmare. For other academic discussions, see: Editorial Comments, The EU's Accession to the ECHR - a 'No' from the ECJ! (2015) 52(1) Common Market Law Review 1; P. Eckhout, Opinion 2/13 on EU Accession to the ECHR and Judicial Dialogue: Autonomy or Autarky? (2015) 38 Fordham International Law Journal 955.

36 D. Halberstam, quoted supra, n. 35, p. 114. For further reading on pluralism, see A. Von Bogdandy, Pluralism, Direct Effect, and the Ultimate Say: On the Relationship between International and Domestic Constitutional Law (2008) 6 International Journal of Constitutional Law 397.

37 For a discussion on this topic from the perspective of international law and whether its supremacy should yield to certain domestic demands, see A. Nollkaemper, Rethinking the Supremacy of International Law (2010) 65 Zeitschrift Für Öffentliches Recht 65.

${ }^{38}$ P. Eeckhout, quoted supra, n. 35, p. 989.
}

CONSTITUTIONAL LAW REVIEW 
Solange and Bosphorus ${ }^{39}$ doctrines, acknowledged that the CJEU provides equivalent fundamental rights protection to the German Constitution or the ECHR. As Wheiler put it, the German Constitutional Court "has a well-earned reputation of a dog that barks but does not bite" ${ }^{40}$. The CJEU, however, did not choose to be docile, but actually took a bite at the relationship between EU law and ECHR law.

Another observation concerns the notion of federalism ${ }^{41}$. Whether we accept it or not, due to the EU not being a state under international law, one cannot deny the functions of the CJEU which are in many ways similar to that of the highest federal courts, protecting the federal level legal order from outside intrusions. Therefore, instead of looking at the CJEU as a regional court, it might be better to start looking at it as a federal type constitutional court, which will police the outside boundaries of the EU legal order.

The question is of course who will benefit and who will lose from this pluralistic, multilevel fundamental rights regime. We have known for several decades now that the CJEU will provide national courts with an interpretation of fundamental rights, "as laid down in particular in the [ECHR]", when the compatibility of MS law had to be assessed for its conformity with fundamental rights in an area falling within the scope of EU $\mathrm{law}^{42}$. In other words, the CJEU has already interpreted provisions of the ECHR which concerned issues over which the EU has competence, without the EU being formally bound by the ECHR. Moreover, the ECtHR was satisfied that the level of fundamental rights protection provided by the CJEU was equivalent to that provided by it. However, with the expansion of EU competences over the last decades in areas such as asylum policy, criminal law (Title V TFEU), and more recently foreign direct investment and the commercial aspects of intellectual property (Article 207 TFEU), the powers of the CJEU also grew and so did the potential for friction with the ECtHR, Member State courts and other international courts.

This potential friction within the multilevel system of fundamental rights protection is mainly due to the elevation of principles specific to the EU legal order to the same level or even above that of fundamental rights. We are now witnessing diverging standards of fundamental rights protection between national constitutional courts, the CJEU and the ECtHR in such areas as criminal law and asylum policy. Take for example recognition in criminal law matters. In Meloni ${ }^{43}$ the CJEU held that the Spanish Constitutional Court had to change its higher standards of protection of the right to a

\footnotetext{
${ }^{39}$ Bosphorus v. Ireland (45036/98) [2005] ECHR (30 June 2005).

${ }^{40}$ J.H.H. Wheiler, Editorial. The Lisbon 'Urteil' and the Fast Food Culture (2009) 20(3) European Journal of International Law 505, p. 505. See also D. Halberstam, Ch.Möllers, quoted supra, n. 16.

41 D. Halberstam, quoted supra, n. 35, p. 114.

42 Case C-159/90, Society for the Protection of Unborn Children Ireland [1991] ECR I-4685, para. 31; Case C-299/95, Kremzow v. Austria [1997] ECR I-2629, para. 15.

${ }^{43}$ Case C-399/11, Melloni v. Ministerio Fiscal [2013] ECLI:EU:C:2013:107.
}

STUDIES AND ARTICLES 
fair trial since this would come into conflict with the principle of mutual trust and recognition as enshrined in the Framework Decision on the European Arrest Warrant ${ }^{44}$.

Within the area of asylum, differing levels of protection are emerging between the CJEU and the ECtHR. In N.S. and M.E. ${ }^{45}$, mainly due to the EU principle of mutual trust and recognition, the CJEU held that a Member State can only refuse the transfer of an asylum seeker back to the original Member State where the asylum seeker entered EU territory, if the latter Member State suffers from 'systematic deficiencies' in the protection of asylum seekers ${ }^{46}$. This holding was subsequently restated and clarified in Abdullahi ${ }^{47}$. On the other hand, the ECtHR in Tarakhel v. Switzerland ${ }^{48}$ and Sharifi v. Italy and Greece $^{49}$, provided a higher standard of fundamental rights protection than the $\mathrm{CJEU}^{50}$. The asylum seekers in these cases did not have to prove an overall, systemic deficiency in the asylum system, but had to prove a less stringent, in concreto "real risk" of treatment contrary to Article 3 ECHR.

From the above, it can be concluded that the beneficiary of these latest developments is surely the Court of Justice, which has sent a clear message that in every area that falls under EU competence, even if fundamental rights are concerned, it is the final arbiter. The ones who will suffer the losses are numerous. First, private parties can ultimately face even longer proceedings with possible diverging judicial avenues and diverging levels of fundamental rights protection before national constitutional courts, the CJEU or the ECtHR. Second, the principle of legal certainty is affected, since the same right can be interpreted in divergent ways by various courts. Third, Member State courts and authorities will also be faced with the dilemma of not knowing which judgment or decision to enforce in their own legal orders, if a conflict exists between them. Fourth, the relationship between the CJEU and the ECtHR with a previously fairly well functioning judicial dialogue will surely suffer.

The ultimate question is of course whether the current situation was needed. The criteria laid down by the CJEU in Opinion 2/13 are so high that it is difficult to imagine

\footnotetext{
${ }^{44}$ For a short commentary, see V. Franssen, Melloni as a Wake-up Call - Setting Limits to Higher National Standards of Fundamental Rights Protection (2014), available at http://europeanlawblog.eu/?p=2241, accessed 27 January 2015. For a recent twist, see the German Constitutional Court's reaction in a similar case and its indirect critique of the Melloni doctrine. S. Peers, The German Constitutional Court and the European Arrest Warrant: The latest twist in the judicial dialogue (2016), available at http://eulawanalysis.blogspot.co.uk/2016/ 01/the-german-constitutional-court-and.html, accessed 27 January 2015.

45 Joined Cases C-411/10 and C-493/10, N.S. and others v. Secretary of State [2011] I-13905.

46 Ibidem, para. 89. For a short overview of the principle of mutual trust in EU law, see Sz. Gáspár-Szilágyi, Mutual Trust before the Court of Justice - a view from CJEU Judge Sacha Prechal (2015) available at https://acelg.blogactiv.eu/2015/11/11/mutual-trust-before-the-court-of-justice-a-view-from-cjeu-judge-sacha-p rechal/, accessed 27 January 2015.

${ }^{47}$ C-394/12, Abdullahi v. Bundesasylamt [2013] ECLI:EU:C:2013:813.

48 Tarakhel v. Switzerland (29217/12) ECHR (4 November 2014).

${ }^{49}$ Sharifi v. Italy (16643/09) [2014] ECHR (21 October 2014).

50 See S. Peers, Tarakhel v. Switzerland: Another Nail in the Coffin of the Dublin System? (2014), available at http://eulawanalysis.blogspot.nl/2014/11/tarakhel-v-switzerland-another-nail-in.html, accessed 27 January 2015.
} 
how they can be met in the legal text of a renegotiated Accession Agreement to the ECHR and whether in the current political climate a renegotiation is even possible. Moreover, even though one might understand the CJEU's ultimate wish to protect the autonomy of the EU legal order, the question is whether this was in fact necessary? Other high courts, which have their legitimacy based in a national constitution, have accepted the jurisdiction of the ECHR without much fuss and without having their own legal orders being affected by it. In light of this, it is difficult to understand why the CJEU, which has its source in an international treaty, would consider that the ECtHR would somehow undermine the autonomy of the EU legal order.

\section{Division of competences}

A second and equally important building block for the EU's constitutional architecture vis-à-vis the international legal order concerns the internal division of competences between the EU and the Member States. Since the Lisbon Treaty entered into force, the EU has a written catalogue of exclusive, shared, complementary and supporting competences, expressly laid down in Articles 3-6 TFEU, which also codify existing CJEU case-law on EU external competences. ${ }^{51}$ These articles are then given specific expression in the various articles that constitute the legal bases on which the EU can act in a certain field ${ }^{52}$.

Competences or "powers" in US legal parlance are of utmost importance in any federal or federal type system, in which the constituent States of the federation/federal type/supranational ${ }^{53}$ entity confer a part of their powers and sovereignty to a higher level of "government" and governance. Competences are thus a product of the principle of conferral ${ }^{54}$ and delineate the areas in which the federal and the sub-federal level institutions can act either individually or jointly. Competences are of course not static and evolve over time, either through the actions of the federal level institutions or that

\footnotetext{
51 Take for example Article 3 para. 2 TFEU: "The Union shall also have exclusive competence for the conclusion of an international agreement when its conclusion is provided for in a legislative act of the Union or is necessary to enable the Union to exercise its internal competence, or in so far as its conclusion may affect common rules or alter their scope". This provision is a codification of the CJEU's case-law on external EU competences. See B. Van Vooren, R.A. Wessel, EU External Relations Law. Text, Cases and Materials (CUP, 2014), pp. 106-108.

52 For e.g. in external matters Article 207 TFEU (Common Commercial Policy), Article 217 TFEU (Conclusion of Association Agreements) etc. On this discussion, see B. Van Vooren, R.A. Wessel, quoted supra, n. 51, pp. 78-79.

${ }^{53}$ For reasons of space and simplicity the terms "federal" and "sub-federal" shall be used from now on.

${ }^{54}$ According to Article 5 para. 2 TEU: "Under the principle of conferral, the Union shall act only within the limits of the competences conferred upon it by the Member States in the Treaties to attain the objectives set out therein. Competences not conferred upon the Union in the Treaties remain with the Member States". In the United States the Constitution does not confer certain powers to the federal government as a whole, but specific powers are conferred to the various branches of the federal government. See G. Lawson, G.P. Miller, R.G. Natelson, G.I. Seidman, The Origins of the Necessary and Proper Clause (CUP, 2010). The Tenth Amendment of the U.S. Constitution provides that "[t]he powers not delegated to the United States by the Constitution, nor prohibited by it to the States, are reserved to the States respectively, or to the people".
}

STUDIES AND ARTICLES 
of the constituent states. For example, "creeping" competences of the federal level often result from the conduct of the federal level judiciary, when it interprets the powers conferred to the federal level broadly or from the conduct of the federal legislative, when it uses a vague legal basis to include a policy area into the ambit of the federal level ${ }^{55}$. The reverse is also true, since the federal judiciary can also stop the federal legislative from exceeding its own competences. The constituent states can also influence the division of competences, either by opposing ${ }^{56}$ or accepting the competence creep of the federal level, or by amending the founding documents, so to extend or restrict the powers of the federal level. Highest courts situated at the federal level will be tasked with ensuring that the delicate balance and the separation of powers are not only protected from intrusions of the domestic federal and sub-federal level actors, but also from intrusions that originate in the international legal order.

The same holds true for the CJEU, which has created a very complex system of internal and external, exclusive and shared competences between the EU and its Member States ${ }^{57}$. The EU does not only act internally, through regulations, directives or decisions, but it is also an avid international actor. Under Article 216 TFEU it can conclude international agreements which become binding on the EU and its Member States. Such agreements are concluded either solely by the EU or together with the Member States. These latter agreements, also dubbed "mixed" agreements, have been the topic of ample academic discourse ${ }^{58}$ and have certainly caused a fairly complex CJEU case-law, to which we shall turn back to in Section IV.

For now let us focus on the usage of the division of competences by the CJEU as an outside barrier of the EU legal order. As mentioned, EU fundamental rights constitute such a barrier, which even the highest sources of international law must respect. The same holds true for the internal division of competences. The CJEU has held in its famous Mox Plant judgment that an international agreement (in this case the UN Convention on the Law of the Sea) to which the EU is a party "cannot affect the allocation of responsibilities defined in the Treaties and, consequently, the autonomy of the [EU] legal system" ${ }^{29}$. This holding was subsequently consolidated in Kadi I in which the CJEU held that an international agreement "cannot affect the allocation of powers fixed by the Treaties, or consequently, the autonomy of the [EU] legal system" ${ }^{\prime 60}$. The

\footnotetext{
55 The "cross-border" element doctrine developed by the Court of Justice to expand the reach of EU Law is similar to the way in which the US Supreme Court has used the "commerce clause" to apply federal law in areas that are reserved to the States. See also D.T. Coenen, Constitutional Law: The Commerce Clause, Foundation Press, 2004.

${ }^{56}$ Such and opposition can be seen from the Czech Constitutional Court since it held that the CJEU in delivering on of its preliminary rulings has acted ultra vires. See J. Komárek, quoted supra, n. 16.

57 Foundational cases in this area are Case 22/70, Commission v. Council (AETR-ERTA) [1971] ECR 00263; Opinion 1/76 [1977] ECR 741; Opinion 2/91 [1993] ECR I-1061; Opinion 1/03 [2006] ECR I-1145.

${ }^{58}$ For further reading, see Ch. Hillion, P. Koutrakos (eds), Mixed Agreements Revisited: The EU and its Member States in the World (Hart, 2010).

${ }^{59}$ Case C-459/03, Commission v. Ireland (Mox Plant) [2006] ECR I-4635, para. 123.

${ }^{60}$ Kadi I, quoted supra, n. 22, para. 282.
}

CONSTITUTIONAL LAW REVIEW 
observance of this is ensured by the CJEU through its exclusive jurisdiction, which forms a part of the "very foundations of the [EU]"61. As evident also from the previous fundamental rights discussion, the underlying rationale in these cases is the same: the protection of the autonomy of the EU legal order and the protection of the exclusive jurisdiction of the CJEU to interpret and apply EU law, which belong to the very foundations of the EU ${ }^{62}$.

Situations in which the internal division of competences of the EU could be affected by international law are diverse. In several Article 218 para. 11 TFEU Opinions the CJEU found that agreements to which the EU wanted to adhere to did not provide sufficient guarantees for the protection of the EU's internal division of competences. In Opinion $1 / 91(E E A \text { I })^{63}$ the Court found the envisaged EEA Agreement to be incompatible with EU law. One of the motives was that the proposed EEA Court was granted the power to settle disputes between the "contracting parties" to the envisaged agreement, which were the former EC, the Member States and the EFTA states. Since the EU Member States would have also been parties to the envisaged agreement, the proposed EEA Court could have potentially heard disputes between the EU and its Member States. According to the CJEU, such a power was likely to adversely affect the allocation of responsibilities between the EU and its Member States as provided in the EEC Treaty. Furthermore, this would have adversely affected the autonomy of EU Law, since under current Article 344 TFEU (ex-Article 219 EEC Treaty) the CJEU has exclusive jurisdiction over disputes arising between EU Member States ${ }^{64}$. Similar problems were found in the Accession Agreement to the ECHR. In Opinion 2/13 the CJEU was of the opinion that the co-respondent mechanism under the Accession Agreement was not up to the standards required by the EU legal order. The ECtHR's assessment of the criteria governing the attributability of an act or an omission to the EU or to the Member States would presuppose an assessment of EU law, more specifically the provisions governing the division of powers between the EU and its Member States ${ }^{65}$.

Unlike in the afore-mentioned two opinions, in the previous Mox Plant case the international agreement had already entered into force. Even so, the CJEU held that Article 344 TFEU was breached since two EU Member States had submitted a dispute before a foreign tribunal concerning a matter also covered by EU law. In such cases the risk exists that the foreign tribunal could decide on the responsibility of Member States, which would affect the exclusive jurisdiction of the CJEU under Article 344 TFEU. This

\footnotetext{
61 Ibidem, with reference to Opinion 1/91 [1991] ECR I-6079, para. 35 and 71, and Case C-459/03, Commission v. Ireland [2006] ECR I-4635, para. 123.

${ }^{62}$ For a detailed discussion, see T. Lock, The European Court of Justice and International Courts (Routledge, 2015), pp. 114-127.

${ }^{63}$ Opinion 1/91 (EEA Agreement) [1991] ECR I-60709.

${ }^{64}$ Ibidem, para. 35. This idea is discussed further in Sz. Gáspár-Szilágyi, A Standing Investment Tribunal: The Commission Trying to Please the 'Cabbage' and the 'Goat', but what About the Court?. This manuscript is currently under review by The Journal of World Investment and Trade.

65 Ibidem, para. 221-224.
} 
would in turn affect the internal division of competences and it would overall affect the autonomy of EU law.

This of course makes the future negotiation of 'mixed' international agreements by the EU very cumbersome. The CJEU will not agree to an agreement in which a foreign court would have to decide on issues of responsibility of the EU or its Member States because such an exercise would ultimately empower the foreign tribunal to interfere with the internal division of competences within the EU. In turn, this would amount to an interference with the autonomy of EU Law and the exclusive jurisdiction of the CJEU. A way out of this is by concluding sole EU agreements, to which the Member States are not parties. In Opinion 1/00 the Court concluded that the envisaged Agreement for a European Common Aviation Area (ECAA) between the former EC, the EFTA States and former candidate Central and Eastern European States did not affect the allocation of powers between the EU and its MS since the MS were not parties to the agreement. This meant that the term 'contracting parties' could not be interpreted in a manner incompatible with EU law and no Article 344 TFEU situations would arise ${ }^{66}$.

For now it can be concluded that the very foundations of EU law, fundamental rights, the internal division of competences between the EU and its Member States, and the exclusive jurisdiction of the CJEU, can be seen as a form of "super-supreme law" 67 from which no derogations are possible ${ }^{68}$.

\section{Primacy, review of legality and international law}

Domestic constitutional orders do not only provide for a set of core constitutional values which all other legal orders must respect, but they also provide for rules on how the norms coming from a different legal order interact with their own domestic legal $\operatorname{order}^{69}$. Domestic constitutional orders in their relation with the international legal order have some basic questions to answer: (a) Is international law a part of the domestic legal order? (b) What level does international law occupy in the internal hierarchy of norms? (c) What happens in case of a conflict between a domestic norm and an international norm?

These are highly complex questions, which are handled very differently by the various domestic legal orders. This has been amply discussed in legal academia ${ }^{70}$ and

\footnotetext{
${ }^{66}$ Ibidem, para. 15-17.

${ }^{67}$ C. Eckes, Protecting Supremacy from External Influences: A Precondition for a European Constitutional Legal Order (2012) 18(2) European Law Journal 230, p. 241; see also A. Rosas, L. Armati, EU Constitutional Law (Hart, $2^{\text {nd }}$ ed., 2012), pp. 54-55.

${ }^{68}$ Kadi I, quoted supra, n. 22, para. 304.

${ }^{69}$ See Article VI, Clause 2 (Supremacy Clause), US Constitution; Articles 93-94 of the Constitution of the Kingdom of the Netherlands; Article 11 of the Constitution of Romania.

70 D. Sloss (ed.), The Role of Domestic Courts in Treaty Enforcement (CUP, 2010); D.L. Sloss, M.D. Ramsey, W.S. Dodge (eds), International Law in the U.S. Supreme Court. Continuity and Change (CUP, 2011); P.J. Slot (ed.), Views of European Law from the Mountain (Wolters Kluwer, 2009); D. Shelton (ed.), International Law and Domestic Legal Systems (OUP, 2011).
} 
has been the focus of my own research ${ }^{71}$. Therefore, these few paragraphs cannot do proper justice to an otherwise highly complex area of the law. Even so, relying on previous studies of my peers and of my own I will try to convey to the reader an image of how the 'architect' of the EU legal order protects the order's autonomy when confronted with the domestic enforcement of international law.

With regard to the question of the integration of international law into the domestic legal order, the traditional view is that of monism and dualism ${ }^{72}$. However, I would prefer to use the terms direct or indirect integration. In case of direct integration no further acts of transposition are needed to make international law a part of the domestic legal order or to make it operative in the domestic legal order as if it were national law ${ }^{73}$. As is well known, international law is mainly made up of international agreements, customary international law and the decisions of international adjudicatory bodies (handled in Section V). With regard to international agreements, the EU Treaties only provide in Article 216 TFEU that international agreements to which the EU is a contracting party are binding on the EU and its MS from their entry into force. The question of integration and effects is a result of the CJEU's extensive case-law. From Haegeman $^{74}$ onwards we know that international agreements which are binding on the EU ("EU international agreements") form an integral part of the EU legal order without further transposing measures being necessary. Concerning customary international law the CJEU has held that the EU is bound to observe international law in its entirety, when it adopts an act, including customary international law, which is binding on the EU institutions. Furthermore, secondary EU law can be reviewed in light of customary international law ${ }^{75}$.

The question of hierarchy matters as well and each domestic legal order answers this question differently. In the United States treaties and federal level congressional legislation are the supreme law of the land, occupying the same level of hierarchy. They rank below the US Constitution, but above State law ${ }^{76}$. In the EU the CJEU held that EU international agreements are ranked below the Founding Treaties and other sources of

\footnotetext{
${ }^{71}$ Sz. Gáspár-Szilágyi, The 'Direct Effect' of EU International Agreements Through a US Lens, PhD thesis (Aarhus University 2015); idem, EU International Agreements through a US lens: Different Methods of Interpretation, Tests and the Issue of 'Rights' (2014) 39(5) European Law Review 601; idem, The 'Primacy' and 'Direct Effect' of EU International Agreements (2015) 21(2) European Public Law 343; idem, The Horizontal Direct Effect of EU International Agreements. Is the Court Avoiding a Clear Answer? (2015) 42 (2) Legal Issues of Economic Integration 93.

72 The line between dualism and monism is often blurred by the courts. The courts of some dualist countries have developed judicial strategies for the application of unincorporated treaties. Monist courts on the other hand developed certain judicial avoidance techniques for the direct application of treaties. See D. Sloss, Domestic Application of Treaties, in D.B. Hollis (ed.), The Oxford Guide to Treaties (OUP, 2012), pp. 372-376.

${ }^{73}$ For e.g., unlike EU international agreements, which form an integral part of EU law, agreements concluded by the Netherlands are not considered Dutch Law, but law which is operative in the Netherlands. E.A. Alkema, Netherlands, in D. Shelton (ed.), International Law and Domestic Legal Systems (OUP, 2011), pp. 416-417.

${ }^{74}$ Case 181/73, Haegeman v. Belgium [1974] ECR 00449.

${ }^{75}$ Case C-366/10, Air Transport Association of America [2011] ECR I-13755, para. 101-102.

${ }^{76}$ Article VI, Clause 2, US Constitution.
}

STUDIES AND ARTICLES 
primary EU law but above secondary EU law ${ }^{77}$ and the laws of the Member States ${ }^{78}$. From this, one might argue that in case of a conflict between an EU international agreement and secondary EU law/Member State law, the correct answer will be provided by the hierarchically superior nature of EU international agreements. Unfortunately, the answer is not black and white.

This leads us to the question of conflict between EU law/MS law and EU international agreements. The answer here is a nuanced one and several observations need to be made. First, as discussed in Section II, international law must respect the core values of EU law. Thus in the case of a conflict between an EU international agreement and EU primary law, the latter will prevail. Second, regarding a conflict between secondary EU law and EU international agreements, I have argued in a previous work, that the primacy of EU international agreements over secondary EU law needs to be triggered by some form of direct effect and primacy in itself is not enough to set aside inconsistent secondary EU law $^{79}$. Third, when it comes to MS law the situation will differ according to whether the EU or the MS have competencies over the agreement or parts of mixed agreements. The CJEU has decided that MS courts are free to grant effects to international agreements or parts of them as they please if the MS have exclusive competences over them ${ }^{80}$. Fourth, recent research not only in the EU but also in other jurisdictions has shown that domestic federal courts will resort to protectionist strategies when confronted with the review of federal-level domestic legislation in light of international norms, but will be more lenient towards international law when sub-federal level domestic norms are to be reviewed in light of international norms ${ }^{81}$.

And this brings us to the CJEU's case-law regarding the review of secondary EU law and MS law in light of EU international agreements. With regard to the review of secondary EU legislation, the CJEU has resorted to protectionist techniques. For example, the CJEU will excessively rely on purposive interpretation to the detriment of textual interpretation ${ }^{82}$. Following this, the CJEU will conclude that the international agreement is not directly applicable or does not have direct effect. Sometimes, even if the agreement does have direct effect no incompatibility is found between the

\footnotetext{
77 Under Article 288 TFEU these are regulations, directives and decisions.

${ }^{78}$ Case C-61/94, Commission v. Germany [1996] ECR I-3989, para. 52; Case C-286/02, Bellio [2004] ECR I-3465, para. 33; Case C-308/06, Intertanko v. Secretary of State [2008] ECR I-04057, para. 42.

${ }^{79}$ Sz. Gáspár-Szilágyi, The 'Primacy' and 'Direct Effect' of EU International Agreements, quoted supra, n. 71.

80 Joined Cases C-300/98 and C-392/98, Dior [1998] ECR I-11344, para. 49; Case C-431/05, Merck Genéricos [2007] ECR I-7001, para. 34; Case C-240/09, Lesoochranárske zoskupenie (Slovak Brown Bear) [2011] ECR I-1255, para. 31-32.

${ }^{81}$ Sz. Gáspár-Szilágyi, PhD thesis, quoted supra, n. 71, at Chapter 3 and 7; M. Mendez, The Legal Effects of EU Agreements. Maximalist Treaty Enforcement and Judicial Avoidance Techniques (OUP, 2013); C.M. Vázquez, Judicial Review in the United States and in the WTO: Some Similarities and Differences (2004) 36 George Washington International Law Review 587. However, in recent years US courts have shown a more protectionist attitude towards sub-federal level measures as well. See L.F. Damrosch, Medellin and Sanchez-Llamas: Treaties from John Jay to John Roberts, in D.L. Sloss, M.D. Ramsey, W.S. Dodge (eds), International Law in the U.S. Supreme Court - Continuity and Change (CUP, 2011).

${ }^{82}$ Sz. Gáspár-Szilágyi, EU International Agreements through a US lens, quoted supra, n. 71, pp. 608-615.
} 
challenged EU legislation and the international norm ${ }^{83}$. Furthermore, in politically sensitive cases the CJEU will defer to the will of the EU political bodies ${ }^{84}$ and more recently the CJEU has severely restricted any type of existing exceptions to the non-direct effect of international agreements ${ }^{85}$. On the other hand, when it comes to MS legislation or MS measures, the CJEU is a lot more willing to enforce the international norm and will often find an incompatibility between the MS measure and international law ${ }^{86}$.

This is not at all surprising if one looks at how federal courts function. Whether we accept or not that the EU is a federal type entity, as Halberstam has noted, we cannot avoid the f-word; "federalism" 87 . The CJEU does certainly not avoid acting like a federal court. In the United States authors have already argued that the US federal courts will use protectionist techniques when the actions or acts of the federal level institutions do not conform to the tenets of international law. On the other hand, they will not show the same level of protectionism towards sub-federal State measures ${ }^{88}$. This of course can be explained by what has been espoused in the beginning of this work. Highest federal courts will try protecting the federal level both from the intrusions of international law and sub-federal law. In these cases, the mishaps of sub-federal level institutions could bring about the international responsibility of the federation as such, a situation which the federal courts will try to avoid. On the other hand, if they challenge the express wishes of other federal level institutions, they might upset the institutional balance between the various federal level institutions.

From the above it can be concluded that the CJEU, even though committed to the enforcement of EU international obligations, once again takes with one hand what it has given with the other. It held that EU international agreements form an integral part of the EU legal order and that they rank above secondary EU law and MS law. However, when confronted with actual conflicts between EU law and international law, it will resort to protectionist techniques. On the other hand, the same conduct is not noticeable when MS law or measures are incompatible with the EU's international obligations. Therefore, the federalist court tendencies in the operation of the CJEU are quite evident. The main difference is of course that the EU is not a federation per se and its Member States are still sovereign international actors.

\footnotetext{
${ }^{83}$ For a further reading, see M. Mendez, The Legal Effect of Community Agreements: Maximalist Treaty Enforcement and Judicial Avoidance Techniques (2010) 21(1) European Journal of International Law 83.

${ }^{84}$ An argument used extensively in the context of the effects of WTO Law. See Joined Cases C-120/06 P and C-121/06 P, FIAMM v. Council and Commission [2008] ECR I-06513, para. 174.

${ }^{5}$ Sz. Gáspár-Szilágyi, The Relationship between EU law and International Agreements. Restricting the Fediol and Nakajima Exceptions in Vereniging Milieudefensie (2015) 52(4) Common Market Law Review 1059.

${ }^{86}$ See for e.g. Case C-61/94, Commission v. Germany (International Dairy Agreement) [1996] ECR I-4006; Case C-13/00, Commission v. Ireland (Berne Convention) [2002] ECR I-02943; Case C-239/03, Commission v. France (L'Étang de Berre II) [2004] ECR I-9328.

87 D. Halberstam, quoted supra, n. 35, p. 114.

${ }^{88}$ For a detailed reading, see .L. Sloss, M.D. Ramsey, W.S. Dodge, quoted supra, n. 70.
} 


\section{The relationship with other international tribunals}

Thus far we have seen a CJEU that has shielded the very core of the EU legal order, fundamental rights and the internal division of competences, from the international legal order. Internally, the CJEU also shows a protectionist attitude when secondary EU law is in a possible breach of the EU's international obligations, but it is keen on enforcing EU international obligations against Member States, if the conduct of the Member States could result in the EU's responsibility on the international plane. Another pertinent issue is the way in which the CJEU interacts with other international courts, or international adjudicatory bodies.

International courts or international adjudicatory bodies, unlike national courts, result from international agreements. The proliferation of international agreements in the second half of the $20^{\text {th }}$ century also lead to a proliferation of international and regional courts which can be classified in different ways, such as according to their subject matter or the way in which they operate. Some international or regional tribunals, such as the International Court of Justice (ICJ), the Appellate Body of the World Trade Organisation (WTO), the International Tribunal for the Law of the Sea (ITLOS) and the ECtHR are standing international/regional courts that result from multilateral agreements. On the other hand, most bilateral trade and investment agreements foresee the creation of ad hoc State-to-State or investor-to-State tribunals ${ }^{89}$. Regarding their subject matter, there are courts that handle general international law matters such as the ICJ, or specific matters such as trade (WTO Appellate Body), human rights (Inter-American Court of Human Rights, ECtHR), maritime law (ITLOS) etc. The result of this tangled web of international, regional and national courts is that often the jurisdictions of these adjudicatory bodies overlap. The question then arises of how such courts interact and whether there is judicial dialogue between them.

The CJEU is in the awkward position of being a product of international law, while its functions in many ways are similar to those of national federal courts. One would thus expect the CJEU to engage in judicial dialogue with other international courts, but also to engage in Eurocentric/nationalist tactics when it feels that an international tribunal might affect its own jurisdiction. Whilst within the EU dialogue between the CJEU and Member State courts to some extent is provided by the preliminary reference procedure ${ }^{90}$, which has the main function of ensuring a consistent and homogenous

\footnotetext{
${ }^{89}$ Even though very recently the Commission has proposed the creation of a standing Investment Court System under the envisaged Transatlantic Trade and Investment Partnership with the US. See European Commission, TTIP draft text on Chapter II - Investment, available at http://trade.ec.europa.eu/doclib/docs /2015/november/ tradoc_153955.pdf, accessed 28 January 2016. For a detailed discussion, see Sz. Gáspár-Szilágyi, $A$ Standing Investment Tribunal, quoted supra, n. 64.

${ }^{90}$ For a discussion on the practical difficulties in applying the preliminary reference procedure, see M. De Werd, Dynamics at Play in the EU Preliminary Ruling Procedure (2015) 22(1) Maastricht Journal of European and Comparative Law 150.
} 
interpretation of EU law throughout the EU, no such mechanism exists on the international level. Therefore, the possibility is very present that in case of conflict between an international court and a 'domestic' court, the latter will choose to protect its own legal order, instead of engaging in a dialogue. This would not be a novelty. The US Supreme Court for example has held that they will only give respectful consideration to judgments of the ICJ, but the ultimate judicial authority in the US is vested in the Supreme Court by the US Constitution ${ }^{91}$.

As I have argued in a recent work $^{92}$, the CJEU can influence the relationship between it and international courts in different ways. Under Article 218 para. 11 TFEU, the Member States, the Commission, the Parliament or the Council have the possibility of asking the CJEU to deliver an opinion on whether an envisaged international agreement is compatible with EU law, ex ante, before the agreement enters into force. In case of a negative opinion the agreement cannot enter into force ${ }^{93}$. As the following paragraphs will illustrate, in such cases the contentious issue is often whether an international tribunal which was supposed to be set up by the envisaged agreement is compatible with EU law. However, if the CJEU was not asked for such an opinion and the agreement enters into force or the EU joins a pre-existing agreement which has a functioning international court system, the CJEU still has the possibility to provide an ex post review of the act by which the EU concluded the agreement or to provide a review of a decision rendered by the international tribunal. Furthermore, the CJEU can also hamper the enforcement of the international decision through other means.

With regard to ex ante opinions the CJEU developed an extensive case-law with notable negative opinions ${ }^{94}$. In Opinion $1 / 76^{95}$ the CJEU did not agree to the setting up of a small, regional "Fund Tribunal" under an international agreement between the then EC, plus six Member States and Switzerland, establishing a European laying-up fund for inland waterway vessels. The main reason concerned the presence of CJEU judges in the composition of the Fund Tribunal. From Opinion 1/91 (EEA I) onwards the CJEU introduced a fairly strict test for the compatibility of international courts with EU law, which is based on the protection of the autonomy of the EU legal order and the protection of the exclusive jurisdiction of the CJEU to provide binding interpretations of EU law or to handle disputes between EU Member States in matters that concern EU Law.

This rationale led to the Court saying "no" to the EEA Court in Opinion 1/91, the European and Community Patent Court in Opinion $1 / 09^{96}$ and most recently to the

\footnotetext{
${ }^{91}$ Sanchez-Llamas v. Oregon, 548 U.S. 331 (2006), pp. 333-334.

${ }^{2}$ Sz. Gáspár-Szilágyi, $A$ Standing Investment Tribunal, quoted supra, n. 64.

${ }^{93}$ For a detailed discussion of this procedure, see K. Lenaerts and Others, EU Procedural Law (OUP, 2014), pp. 550-560.

${ }_{94}$ For a more detailed discussion, see B. de Witte, A Selfish Court? The Court of Justice and the Design of International Dispute Settlement beyond the European Union, in M. Cremona, A. Thies (eds) The European Court of Justice and External Relations Law. Constitutional Challenges (Hart, 2014).

95 Opinion 1/76 (Inland Waterways) [1977] ECR 741.

96 Opinion 1/09 (European Patent Court) [2011] ECR I-1137. In this case, however, Article 344 TFEU was not a concern because the envisaged Patent Court would have only handled cases between private parties and not
}

STUDIES AND ARTICLES 
ECtHR in Opinion 2/13. Two positive examples exist as well. The first is the EFTA Court in the follow-up opinion ${ }^{97}$ to Opinion $1 / 91$ and the surveillance mechanism under the $\mathrm{ECCA}^{98}$. However, in both of these cases the international adjudicatory mechanisms did not have the power to deliver binding interpretations of EU law or to handle cases between EU Member States. More so, the powers of EU institutions (the EU Commission and the CJEU) were extended over the whole agreement, with regard to non-EU contracting parties as well.

Ex post review is less common and mainly concerns internal matters, such as the wrong EU institutions concluding an international agreement on an incorrect legal basis $^{99}$. In such cases the EU act concluding the international agreement is annulled, but the agreement as such remains valid under international law. However, in Opinion 1/00 $(E C A A)^{100}$ the Court illustrated that it could not only review the EU acts concluding an international agreement, but also the acts of the decision-making body set up by an agreement. However, doubts remain as to the scope of this ex post review. If a full review of decisions of international bodies was possible, the Court would admittedly be doing what some Member State highest courts are doing in regard to EU law ${ }^{101}$. The review of the decisions of an international tribunal or adjudicatory body is also possible in an indirect manner. Kadi $I$ is a good example that the indirect review of a Security Council Resolution was possible by directly reviewing the implementing EU Regulation.

Finally, the Court can hamper the enforcement of international decisions in politically sensitive areas. The CJEU has held that the decisions of an international tribunal, which is set-up by a non-directly-effective international agreement, cannot be directly enforced in the EU legal order against conflicting EU measures. The CJEU has held in the context of decisions of the WTO Dispute Settlement Body that such decisions do not have direct effect if the underlying agreement does not have direct effect ${ }^{102}$. The possibility of this happening more often is high. As Semertzi has noted in the context of recently concluded EU trade agreements, no-direct effect clauses inserted in recently concluded EU international agreements are becoming the norm. ${ }^{103}$ This means that decisions rendered by international tribunals, which are set-up under such non-directly-effective international agreements, will also lack direct effect in the EU legal order.

\footnotetext{
Member States. For further reading, see K.P. Mahne, A Unitary Patent and Unified Patent Court for the European Union: An Analysis of Europe's Long Standing Attempt to Create a Supranational Patent System (2012) 94(2) Journal of the Patent and Trademark Office Society 162.

97 Opinion 1/92 (EEA II) [1992] ECR I-02821.

98 Opinion 1/00 (European Common Aviation Area) [2002] ECR I-3493.

${ }^{99}$ Case C-327/91, France v. Commission [1994] ECR I-3641; Case C-233/02, France v. Commission [2004] ECR I-02759.

100 Opinion 1/00 (European Common Aviation Area) [2002] ECR I-3493.

101 F. Castillo de la Torre, Opinion 1/00, Proposed Agreement on the Establishment of a European Common Aviation Area (2002) 39(6) Common Market Law Review 1373, p. 1389.

102 FIAMM and Fedon, quoted supra, n. X, para. 126-128. See also Sz. Gáspár-Szilágyi, A Standing Investment Tribunal, quoted supra, n. 64.

${ }^{103}$ A. Semertzi, The Preclusion of Direct Effect in the Recently Concluded EU Free Trade Agreements (2014) 51 Common Market Law Review 1125.
} 
In conclusion, the CJEU prefers to act like a protectionist domestic court, instead of committing itself to international comity and dialogue. Such actions of the CJEU have already caused frictions with ITLOS ${ }^{104}$, have frustrated WTO partners, and recently seem to have upset an otherwise good working relationship with the ECtHR. The possibility to see even more friction in the future will increase. As discussed, the powers of the EU in the last two decades have grown substantially. Asylum policy, criminal law, civil cooperation, data privacy, foreign direct investment, intellectual property now all fall under the CJEU's jurisdiction ${ }^{105}$. Signs of friction already exist in investment law with regard to the existence of intra-EU BITs and awards rendered under such agreements $^{106}$. The question is whether the CJEU is doing more harm than good in this protectionist process. In a pluralistic world, with multiple levels of governance and in an era when heterarchy ${ }^{107}$ is the norm rather than hierarchy, one might wonder whether a strict, domestic protectionist approach is better than fostering judicial dialogue.

\section{Conclusions}

The title of this short writing asked the question whether the CJEU is an overzealous architect of the relationship between the EU legal order and the international one. Unlike most domestic constitutions, the EU Treaties do not provide much technical guidance on how the EU legal order interacts with the international legal order or on the ways in which the CJEU should relate to other international courts. This means that the CJEU was given a free hand to lay down the core constitutional values of the EU legal order, such as fundamental rights and the internal division of competences. The CJEU also created the constitutional framework for the internalization of international law, and provided answers to questions such as the integration, hierarchical position and internal enforcement of international law. Luxembourg has also developed an extensive jurisprudence of how the CJEU and the EU legal order relates to the various international adjudicatory bodies.

Much of this evolution is understandable and in many ways is similar to the attitude of the US Supreme Court over its two centuries of existence. In the beginning the CJEU took more cautious steps, making sure it set-up the foundations (primacy and direct effect) for the relationship between the EU legal order and the Member State legal orders. It also set out the basic idea that EU international agreements form an

\footnotetext{
${ }^{104}$ For a discussion on how ITLOS views its jurisdiction with regard to the CJEU, see T. Lock, quoted supra n. 62, p. 119.

105 One major policy area in which the Court has restricted jurisdiction is the Common Foreign and Security Policy. See Article 21 para. 4 TEU.

${ }^{106}$ Such are the Micula cases (T-646/14; T-694/15; T-704/15) currently pending before the General Court.

107 On the issue of heterarchy, see: M. Avbelj, Supremacy or Primacy of EU Law - (Why) Does it Matter? (2011)

17 European Law Journal 744; D. Halberstam, Constitutional Heterarchy: The Centrality of Conflict in the European Union and the United States, in J.L. Dunoff, J.P. Trachtman (eds), Ruling the World? Constitutionalism, International Law and Global Governance (CUP, 2009).
} 
integral part of the EU legal order from their entry into force, without further transposition measures being required. However, with the evolution and consolidation of the EU as a global economic power, with a high normative influence, and with the expansion of the powers of the EU into fields previously covered by Member State competences, one cannot but notice a highly federalist tendency in the Court's jurisprudence. All of a sudden the EU legal order becomes a type of federal level legal order, which needs to be protected from both the international and the sub-federal legal orders. And this is how we start seeing a strong, federal type constitutional court and not a regional economic court. This Court is only prone on creating a dialogue with the international legal order if the conditions laid down by it are met.

These conditions, however, are increasingly difficult to meet. The Court takes a very formalistic view on the protection of EU fundamental rights and the protection of the internal division of competences between the EU and the Member States. These core values also open up a whole array of situations in which the CJEU can argue that international law will be ignored since it does not comply with the EU legal order's fundamental values. The same protectionist attitude is also visible when the EU institutions through their acts and measures do not live up to the EU's international obligations, even though the CJEU itself held that EU international agreements have primacy over secondary EU law within the EU legal order. More so, the attitude of the CJEU towards international courts is one which does not seem to be capable of compromises, even though according to once again the CJEU an international agreement which provides for its own system of courts is "in principle" compatible with EU law ${ }^{108}$.

All this creates the impression that the CJEU gives with one hand, but takes away with the other. Now, as explained in this paper, such attitudes are not uncommon among national constitutional or supreme courts. However, these developments of the Court raise several concerns. First, one cannot but help notice the dichotomy between this image the EU tries to portray to the outside world that it respects international law, but as soon as even a theoretical possibility exists that international law will touch upon sensitive EU issues, the CJEU puts on its protectionist cloak. Second, it is not entirely sure why on certain occasions the CJEU has gone so far. For example, the relationship between the ECtHR and national courts or authorities is not as rosy as sometimes people would like to portray, but overall the national high courts have accepted the powers of the ECtHR. So if national courts which are grounded in national constitutions are not bothered to accept outside courts and the tenets of international law, why is the CJEU on the defensive? Third, legal certainty will also suffer, since it is more and more difficult to know whether someone can use certain venues provided by international law or such venues will be affected by the rising powers of the CJEU. Fourth, one cannot but wonder whether in such a pluralistic world judicial dialogue and interaction with other legal orders is not a better solution than building fences around the EU legal order.

\footnotetext{
108 Opinion 1/91, quoted supra, n. 63, para. 40-70; Opinion 1/09, quoted supra, n. 96, para. 74; Opinion 2/13, quoted supra, n. 33, para. 182.
}

CONSTITUTIONAL LAW REVIEW 